

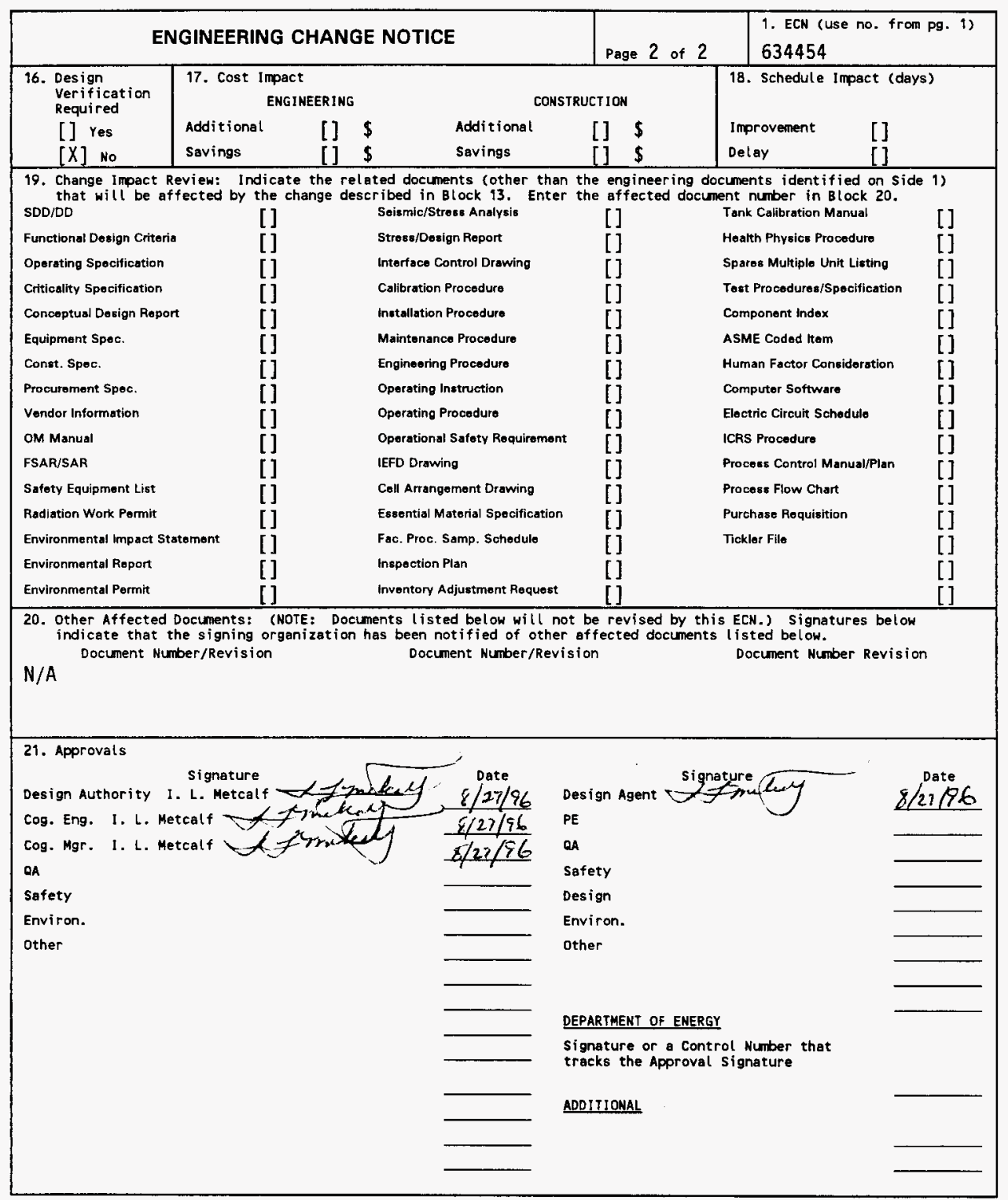




\title{
Shutdown Plan for the 300 Area Fuel Supply Facilities
}

\author{
I. L. Metcalf \\ Westinghouse Hanford Company, Richland, WA 99352 \\ U.S. Department of Energy Contract DE-ACO6-87RL10930
}
EDT/ECN: $634454 \quad$ UC: UC-2050
Org Code: $19800 \quad$ Charge Code: K33A3
B\&R Code: EW7003000 Tota1 Pages: 36

Key Words: shut down, decontamination and decommissioning (D\&D), Resource Conservation and Recovery Act (RCRA), Fuel Supply Shutdown (FSS), N Fuel, special nuclear material (SNM), Environmental Restoration Contractor (ERC)

Abstract: The 300 Area Fuel Supply Shutdown (FSS) facility is progressing toward shut down and ultimate decontamination and decommissioning. This plan identifies the steps to be taken to transition to a stabilized, shutdown facility ready for turn over to the ERC organization. This revision provides an update of the plan to reflect the facility status at the end of fiscal year 1996.

TRADEMARK DISCLAIMER. Reference herein to any specific commercial product, process, or service by trade name, trademark, manufacturer, or otherwise, does not necessarily constitute or imply its endorsement, recommendation, or favoring by the United States Government or any agency thereof or its contractors or subcontractors.

Printed in the United States of America. To obtain copies of this document, contact: WHC/BCS Document Control Services, P.O. Box 1970, Mailstop H6-08, Richland HA 99352, Phone (509) 372-2420; Fax (509) 376-4989.
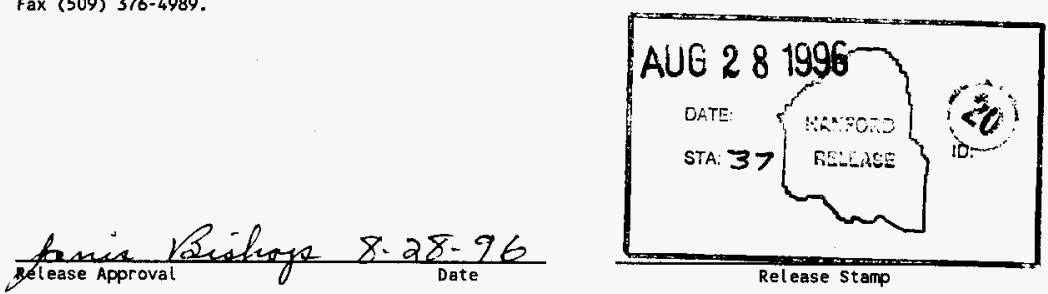

Approved for Public Release 


\section{RECORD OF REVISION}

(2) Title

Shutdown Plan for the 300 Area Fuel Supply Facilities CHANGE CONTROL RECORD

\begin{tabular}{l|l} 
(3) Revision & (4) Description of Change - Replace, Add, and Delet \\
Pages
\end{tabular} Pages

\begin{tabular}{l|l}
0 & (7) Initial Release, EDT 159189
\end{tabular}

$1 \quad$ Annual programmatic update, revised entire document per ECN 627611

2 RS Annual programmatic update, revised entire document per ECN 634454

Authorized for Release

(5) Cog. Engr. 1 (6) Cog. Mgr. Date

SA Dawson

JA Remaize $3 / 30 / 94$

\begin{tabular}{l|l} 
IL Metcalf & IL Metcalf
\end{tabular}

IL Metcalf $3 / 25 / 96$

\begin{tabular}{|l|l|}
\hline & \\
\hline & \\
\hline
\end{tabular}




\title{
SHUTDOWN PLAN FOR THE 300 AREA FUEL SUPPLY FACILITIES
}

\author{
TABLE OF CONTENTS
}

Page

1.0 Introduction and Purpose ...............

2.0 Executive Summary .................. 2

3.0 scope ....................... 4

3.1 Material Inventories ..............7

3.2 Direction .................... 8

3.3 Background ................ . . . 8

3.4 Current Operational Status ............... . 9

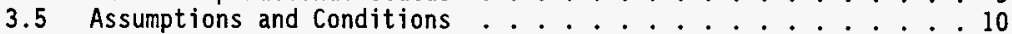

3.6 Environmental Requirements . . . . . . . . . . 10

4.0 Shutdown Plan Activities . . . . . . . . . . . . 11

4.1 Storage and Disposition of Special Nuclear Material . . . . . 12

4.2 Resource Conservation and Recovery Act Closure Plans . . . . . 14

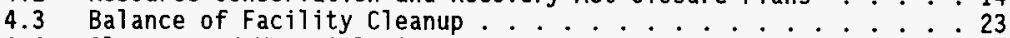

4.4 Cleanup and Material Disposition . . . . . . . . . 29

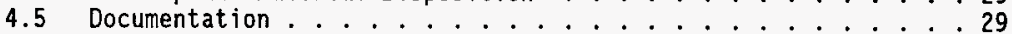

5.0 References ................... 31

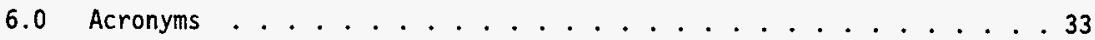

\section{FIGURES}

Figure 1: Fuel Supply Shutdown Facilities in the 300 Area . . . . . . 5

Figure 2: Fuel Supply Shutdown Facilities ........... 6

\section{APPENDIX}

Appendix A: Fuel Supply Special Nuclear Material Inventory . . . . . A-I 


\section{SHUTDOWN PLAN FOR THE 300 AREA FUEL SUPPLY FACILITIES}

\subsection{INTRODUCTION AND PURPOSE}

This shutdown plan was prepared to identify the activities required for shutdown of the Fuel Supply Shutdown (FSS) (N Reactor fuel fabrication) facilities. This document updates the progress of the transition to shutdown of the FSS facility since the Revision 1 release of this document. It addresses the remaining activities required to complete the shutdown, cleanup, and disposition of $N$ Reactor fuel fabrication facilities, equipment, and nuclear material.

The purpose of this shutdown plan is to provide the basic methodology and guidance required to place the FSS facility in a radiologically and environmentally safe condition such that major elements may be shut down and transferred to EM-40. This plan prepares the FSS facility for transfer by placing it in a stabilized state, in accordance with the facility transfer criteria specified in (DOE 1995) and in compliance with state and federal regulations and other applicable U.S. Department of Energy (DOE) orders. This document only describes the scope of the transition to shutdown, and cost and schedule for these activities are identified in the multi-year program plan (MYPP). The MYPP is adjusted each year as dictated by programmatic funding. This document will be revised upon a periodic basis to reflect progress to date. 


\subsection{EXECUTIVE SUMMARY}

The FSS Facility Shutdown Plan is structured to identify the activities required for transition of the FSS buildings to allow for turnover to EM-40. The plan defines the tasks and environmental requirements for the remediation and cleanup efforts for all Hanford Site 300 Area FSS buildings.

The FSS complex consists of 15 buildings, plus a utility trench, burial ground, storage tanks, and a mobile office. For program management purposes, shutdown of these buildings has been separated into three major activities:

- Storage and disposition of special nuclear material (SNM)

- Completion of work defined in the Resource Conservation and Recovery Act of 1976 (RCRA) closure plans for designated facilities, systems, or areas

- Shutdown and cleanup of the remaining facilities for turnover to the Environmental Restoration Contractor (ERC), which is managed by EM-40

At present, SNM is stored in seven buildings $(3712,3716,333,303 \mathrm{~A}$, $303 \mathrm{~B}, 303 \mathrm{E}, 303 \mathrm{G}$ ). The total amount of SNM currently stored in these buildings is less than 1900 metric tons (MT). Currently, a campaign to package and ship 710 metric tons of uranium (MTU) to the United Kingdom (UK) is under way. The stored SNM consists primarily of finished uranium fuel elements, partially finished fuel elements, and billets. This uranium material consists of $0.71 \%$ (natural), $0.95 \%$ and $1.25 \%{ }^{235} \mathrm{U}$ enrichments. In addition, 3.4 MT of uranium powder and 0.47 MT of thorium powder that require disposition are stored in the south portion of the 303K Building. Security, protection, and accountability will be required until an alternate storage location is available or alternate disposition. Acquisition of another storage facility and transfer of this material are not part of this plan. However, a discussion of the options developed in the fuel relocation study (WHC 1994a) is currently under consideration.

Resource Conservation and Recovery Act activities which involve the FSS facilities are described in the following RCRA closure plans:

- 304 Concretion Facility Closure Plan, Rev. 2 (DOE-RL 1990a)

- 303K Radioactive Mixed-Waste Storage Facility Closure Plan (DOE-RL 1990b)

- 300 Area Waste Acid Treatment System (WATS) Closure Plan (DOE-RL 1990c)

- 300 Area Solvent Evaporator (300 ASE) Closure Plan (DOE-RL 1988).

As of this date, both the 304 concretion facility and the 300 ASE are clean closed. The closure plans describe the sampling, characterization, and investigative studies to be performed in these buildings that define their hazard potential and identify any corrective actions required. This plan is based on the expectation that little, if any, remediation work will be 
required, and that the remaining buildings can be defined as clean closed. However, current discussions with Washington Department of Ecology (Ecology) indicate that Ecology may not approve clean closure of soils associated with WATS closure.

The third major activity in this shutdown $\mathrm{plan}$ is to deactivate and clean up the remaining fuel supply facilities such that custody can be turned over to the ERC. Deactivation, cleanup, and stabilization involves all FSS buildings, as well as the process trench external to these buildings. Assets from these facilities will be disposed of in accordance with Westinghouse Hanford Company (WHC) and DOE regulations and procedures. Hazardous and radioactive material in these buildings will be cleaned up or stabilized in accordance with ERC/WHC acceptance criteria. Additional documentation supporting turnover to the decontamination and decommissioning (D\&D) ERC program will be prepared as described in the acceptance criteria (DOE-1995).

A National Environmental Policy Act environmental assessment resulted in a Categorical Exclusion (CX) for Deactivation and Stabilization of the 300 Area Fuel Supply Facilities was approved on August 17, 1994. This CX covers the work detailed in this plan. 


\subsection{SCOPE}

The FSS program includes the activities necessary to place the facilities, buildings, and structures in a condition acceptable for transfer to the ERC (DOE-1995). This shutdown plan identifies the responsibilities, scope, work plans, etc., to accomplish the transition to the ERC shutdown in a cost-effective and environmentally-safe manner.

This plan addresses the following activities related to the shutdown and cleanup of the FSS facility:

- Disposition or consolidation of all nuclear material remaining within the FSS facility

- Tasks required for shutdown, cleanup, and transfer of facility and equipment to the ERC

- Removal and disposition of all radiological and hazardous waste from the facility.

The FSS complex consists of fifteen facilities, plus a utility trench, burial ground, storage tanks, and mobile office. Figure 1 shows an overall plan view of the 300 Area. The area encompassing the FSS buildings is

highlighted in Figure 2. A detailed description of each building is contained in Section 4.0. Major facilities of the FSS complex include:

\section{BUILDING FUNCTION}

$\begin{array}{ll}303 \mathrm{~A} & \text { Finished Fuel Storage } \\ 303 \mathrm{~B} & \text { Uranium Billet Storage } \\ 303 \mathrm{E} & \text { Finished Fuel Storage } \\ 303 \mathrm{~F} & \text { Pumphouse } \\ 303 \mathrm{G} & \text { Uranium Billet Storage } \\ 303 \mathrm{~K} & \text { Mixed and Radioactive Solid Waste Storage } \\ 303 \mathrm{M} & \text { Uranium Oxide Facility (inactive) } \\ 304 & \text { Waste Concretion } \\ 313 & \text { Manufacturing Support } \\ 333 & \text { Fuel Manufacturing (temporary billet storage) } \\ 334 \mathrm{~A} & \text { Waste Acid Storage (inactive) } \\ 334 & \text { Process Sewer Monitoring (inactive) } \\ 3707 \mathrm{G} & \text { Change House } \\ 3712 & \text { Finished Fuel and Billet Storage } \\ 3716 & \text { In Process Fuel Storage and Billet Storage }\end{array}$

The major fuel fabrication operations were conducted in the 313 and 333 Buildings. The 333 Building was the main processing facility and housed equipment for all recent operations. These operations included initial component cleaning to finished fuel assembly, inspection, and packaging for shipment. 


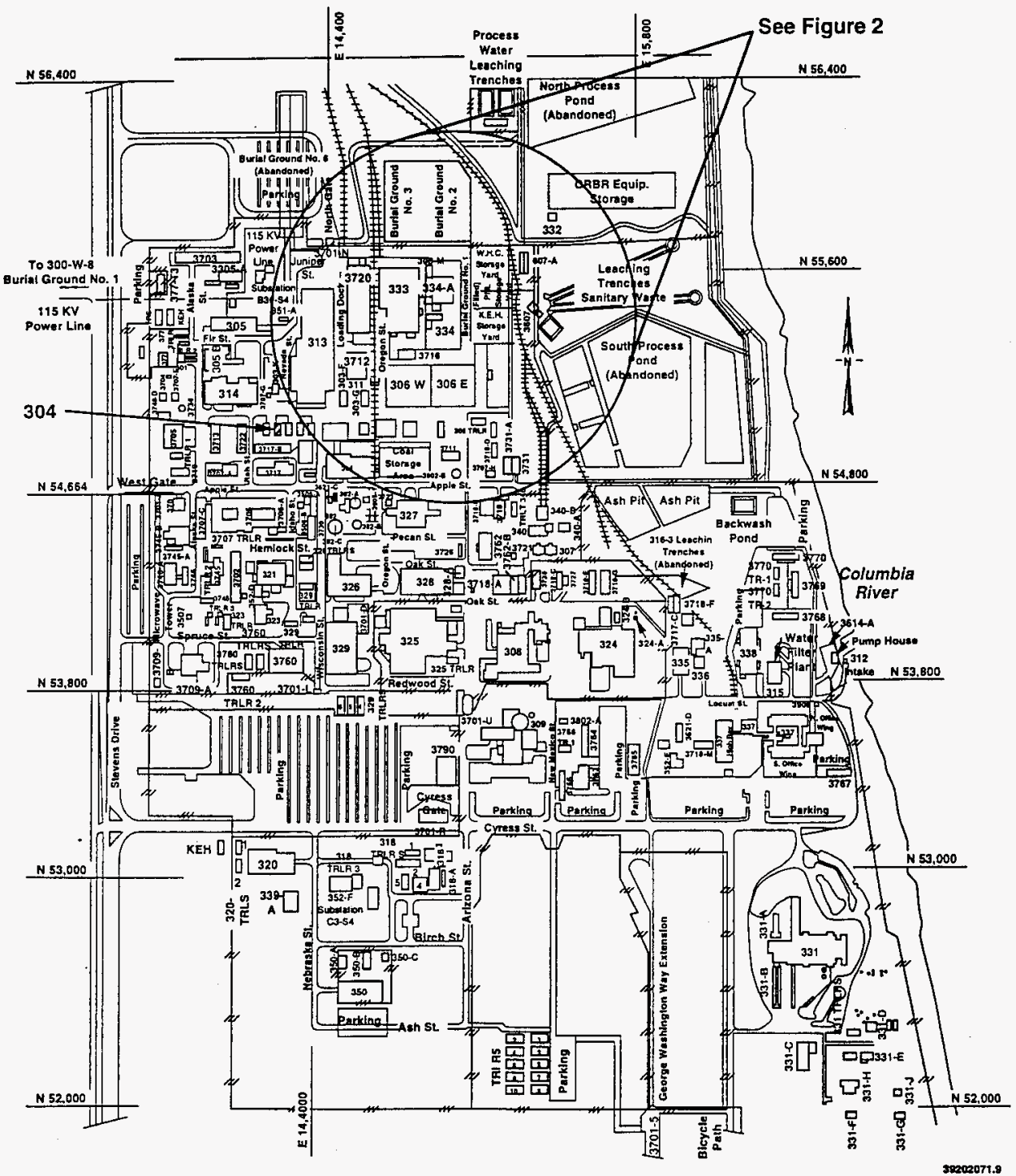

Figure 1 Fuel Supply Shutdown Facilities in the 300 Area 


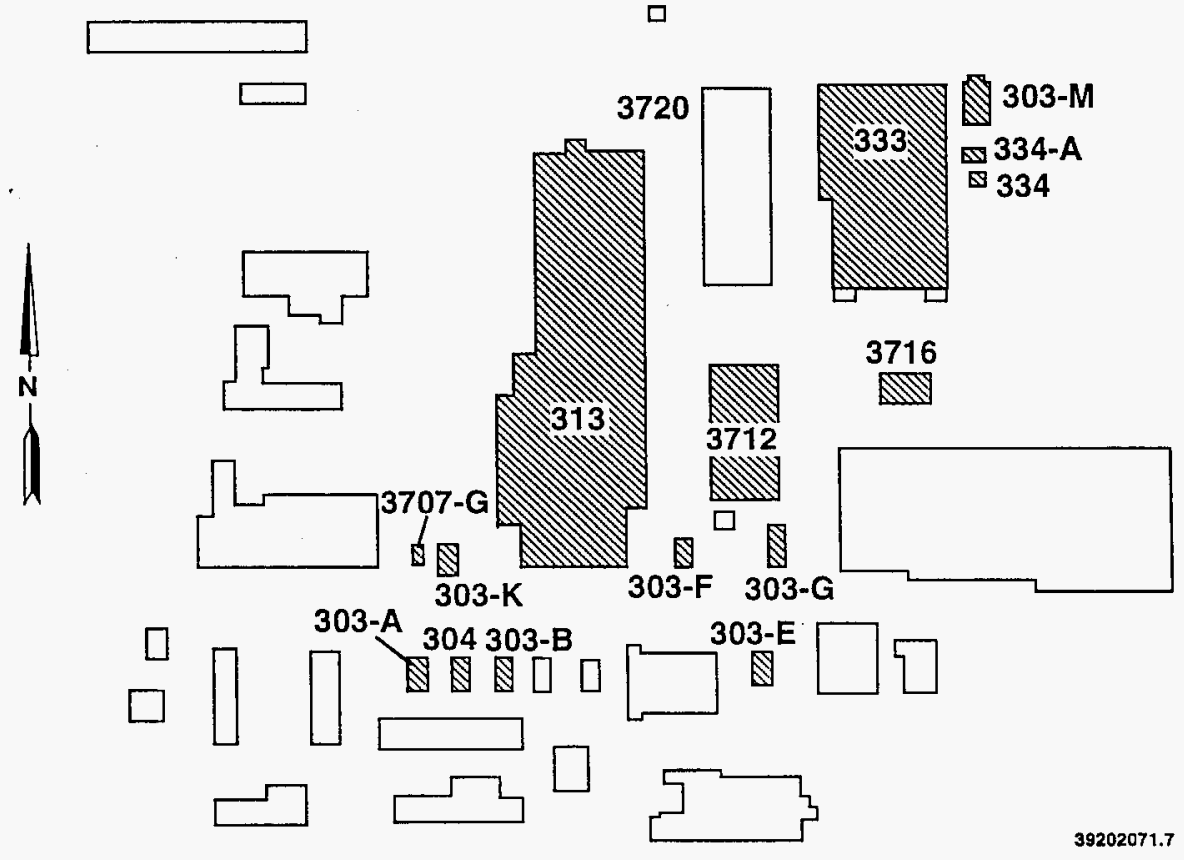

Figure 2 Fuel Suppiy Shutdown Facilities 
The 313 Building was used for manufacturing support, material fabrication, operations, uranium bearing waste acid treatment and provided administrative offices, training, and warehouse space. This building also houses a complete $N$ Reactor pressure tube fabrication facility, which consisted of a 4000-ton Sutton extrusion press, draw bench, grinders, autoclaves, and inspection and chemical cleaning equipment. In cooperation with the City of Richland, the press has been transferred to a private initiative. Expedited isolation of the south portion of the 313 Building is planned due to the unsafe conditions in that area caused by a deteriorating roof.

Cleanup and shutdown of these two buildings represent a major portion of the shutdown activities.

\subsection{MATERIAL INVENTORIES}

Material inventories include all materials which will be removed from the FSS complex prior to turnover of the facility to the ERC.

\subsubsection{Special Nuclear Materials}

$\mathrm{N}$ Reactor fuel material will remain within the FSS complex until an alternate storage facility has been identified. In 1993, fuel material previously located in the 313 Building was consolidated with material currently stored in the other seven FSS storage buildings. A campaign is under way to repackage and ship 710 MTU of billets to the UK.

Turnover of the entire FSS to the ERC is not anticipated until SNM is dispositioned offsite and/or an alternate storage facility(s) has been identified and the transfer completed. Non-SNM facilities could be turned over to the ERC organization as they become available.

This SNM is categorized as work-in-process fuel, uranium billets and finished fuel. A major portion of the material is at an enrichment of either $0.95 \%{ }^{235} \mathrm{U}$ or $1.25 \%{ }^{235} \mathrm{U}$ and is now packaged in wooden boxes in seven buildings within the FSS complex. The remaining SNM consists of enrichments less than $0.95 \%{ }^{235} \mathrm{U}$ (WHC 1994a). Appendix A identifies the SNM inventory in storage at the FSS 300 Area facility projected as of October 1, 1996.

Maintaining SNM fuel storage in the FSS complex will allow only partial cleanup, shutdown, and turnover of the overall facility. Continued surveillance of these facilities, along with building and system maintenance, safeguards and security, and regulatory compliance will be required until the fuel is transferred to an alternate facility/site.

\subsubsection{Fuel Supply Assets}

Assets consist of essential materials, convenience supplies, salvageable materials, office equipment, and fixed and movable equipment. 


\subsubsection{Radioactive and Hazardous Materials}

Radioactive and hazardous materials will be categorized, packaged, transported and dispositioned in accordance with regulatory requirements (DOE-RL 1993) and WHC procedures (WHC 1992a).

\subsection{DIRECTION}

In Ju1y 1991, DOE made the decision to cease preservation of the $\mathrm{N}$ Reactor and to proceed with activities leading to the ultimate decommissioning of the reactor and associated fuel supply facilities. In September 1991, DOE instructed its prime maintenance and operations contractor, WHC, to commence deactivation activities.

\subsection{BACKGROUND}

The history of the N Reactor Fuel Supply complex started in 1943 when the 313 Building was constructed to house manufacturing equipment for aluminum clad uranium fuel for the Hanford Single Pass Reactors. Production of fuel began in mid-1944, using a triple dip process, and continued through the early 1950s. The facility was then expanded to allow conversion of production to a lead dip process for canning the fuel. In the late 1960s, a hot die sizing process was developed and installed. The process included nickel plating of the bare uranium cores prior to cladding. Processing of fuel via hot die sizing and lead dip canning continued until 1971 when the production lines were shut down, along with the single pass reactors. Other programs conducted at the 313 facility include support of a tritium production program from 1948 to 1952 and a thorium program in the 1960s.

Constructed in 1958, the 333 Building houses the primary fabrication equipment for $N$ Reactor fuel. Fuel fabrication operations began in 1962 . From 1965 to 1967 , the facility was also used to assemble lithium aluminate targets for demonstration of coproduction in N Reactor. After 1971, the facility was again dedicated to support fuel fabrication for $N$ Reactor. Fabrication activities continued until $\mathrm{N}$ Reactor entered standby in 1987. Auxiliary operations required to support $N$ Reactor fuel fabrication in the 333 Building used the 313 Building to specifically support scrap processing from the $N$ Reactor fuel fabrication process, incoming component inspection, and fabrication of $\mathrm{Cu}-\mathrm{Si}$ preshapes.

In 1987, the $\mathrm{N}$ Reactor FSS facility began a transition-to-standby status. Unirradiated uranium inventory remains housed in the facility. The uranium is in the form of feed stock billets, finished and unfinished fuel elements, and various scrap forms. Also included are the externally contaminated, unirradiated fuel removed from $\mathrm{N}$ Reactor during the transition-to-dry standby. 


\subsection{CURRENT OPERATIONAL STATUS}

Because some of the equipment has been disassembled for pyrophoric material cleanup and clean closures to enhance the facilities safety posture, the FSS manufacturing equipment is no longer in a standby configuration. A significant unirradiated uranium inventory, present at the time the $N$ Reactor standby was announced, is stored at the facility. Approximately half of the uranium is in the form of extrusion billets. The balance is in the form of fuel elements, some of which were partially completed at the time fabrication ceased. The fuel stored in the $303 \mathrm{~A}$ and $303 \mathrm{E}$ Buildings had previously been loaded into $N$ Reactor, but was never irradiated. The fuel was recovered during reactor defueling with a low level of surface contamination. It has been appropriately packaged for safe handling and storage for the present location in accordance with current procedures.

A minimum operating staff for the facility provides surveillance and basic maintenance. In addition, the operations staff has been involved with the disposal of essential materials and wastes to reduce operational costs. Removal of bulk chemical inventories was completed in April 1991. Cleanup of uranium residuals from fabrication equipment is in progress to reduce radiological concerns. The risk of spontaneous or accidental fires has been eliminated by removal of pyroforic materials. The status of buildings within the FSS complex is described in Section 4.0.

In addition to accommodating the remaining FSS personnel, some of the office and laboratory space within the complex was utilized by other Hanford Site program staff. Relocation of these personnel has been completed. plan:

The following scope has been completed since the original issue of this

Clean closure of the 300 ASE

Clean closure of the 304 concretion facility

Removal and concretion of all pyroforic material

Tank 50 liquid removal

Removal of nonessential materials

- Disposition of spare parts and components

- Clean out of the 313 South Building

- Preparation of the interim storage basis and interim operational safety requirements for the FSS

- 333 Building steam system shutdown

- Relocation of nonstaff occupants from the 333 Building

- Shutdown of the fluid environmental monitoring system

- Shutdown of the criticality monitoring system

- Reduction of 4,670 sq $\mathrm{ft}$ of contamination area (CA)

- Removal of all mixed waste from the 303K Building

- $\quad 313$ Building steam system shut down

- $\quad 313$ South water supply disconnected

- 333 water supply disconnected except for occupied office area

- $\quad 313$ South fire protection sprinkler system disconnected. 
The following shutdowns scope will be completed at the end of FY 1996:

- 311 Tank Farm caustic system

- $304 / 304 \mathrm{~A}$ Buildings

- 303 M Building.

\subsection{ASSUMPTIONS AND CONDITIONS}

Fuel Supply Shutdown operations, including shutdown $\mathrm{planning}$ and execution, are being funded and managed by the Office of Environmental Restoration and Waste Management (EM-60), through RL. Funding for control and surveillance of SNM storage is currently being provided by Defense Programs.

Accomplishment of the shutdown activities contained in this plan assumes that adequate funding to accomplish the stated tasks will be provided in the MYPP time frame described. Funding deficiencies will result in an extended program schedule and a delay in transfer of the facility to ERC.

This shutdown plan is based on the following assumptions:

- The FSS building has no long-term use and will be placed on a schedule for D\&D at some later unspecified date after being transferred to ERC

- All commitments, plans and requirements of RCRA, Tri-Party Agreement (TPA), and regulatory, environmental health and safety criteria will be met

- This plan includes all requirements for asset disposal, document disposition, and SNM management

- Privatization initiatives of the Sutton press was reached during FY 1994; however, a decision on the Lowry press is still pending

- This $\mathrm{plan}$ assumes that RCRA unit work plan implementations and other shutdown activities will be integrated; however, they may proceed independently of each other

- The shutdown program will fund and implement the shutdown of all the designated units in compliance with the approved RCRA closure plans and ERC acceptance criteria

- All fuel will continue to be stored in FSS complex buildings until alternate fuel storage facilities have been provided and/or disposition affected.

\subsection{ENVIRONMENTAL REQUIREMENTS}

All applicable state and federal environmental acts and requirements shall be met during the shutdown of the FSS complex and turnover of these facilities to the ERC. 


\subsection{SHUTDOWN PLAN ACTIVITIES}

The FSS facility Shutdown Plan is structured to identify the remaining activities required for permanent closure of the FSS facilities and transfer to ERC. The $\mathrm{plan}$ defines the tasks and environmental requirements for the remediation and cleanup efforts for all Hanford Site 300 Area FSS facilities.

This section of the plan contains a description of each building within the FSS complex and a discussion of the facilities, equipment, and plans to complete the shutdown. Also included are the tasks required for equipment disposition, fuel consolidation, waste cleanup, and document preparation.

The FSS complex consists of fifteen facilities, plus a utility trench, burial ground, storage tanks, and a mobile office. For program management purposes, shutdown of these facilities has been separated into three major activities:

- Storage and disposition of SNM

- Completion of work defined in each of the RCRA (RCRA 1976) closure plans for designated FSS facilities, systems, or areas

- Shutdown and cleanup of the remaining FSS facilities or portions thereof that are not included in one of the RCRA closure plans.

The 300 Area FSS facilities are located within the 300-FF-2 (source) and 300-FF-5 (groundwater) operable units, as designated in the Hanford TPA (Ecology 1990 et al.). The 300-FF-2 and 300-FF-5 operable units are scheduled to be remediated using the Comprehensive Environmental Response, Compensation, and Liability Act (CERCLA) remediation investigation/feasibility study (RI/FS) process. Therefore, any soil and groundwater contamination not related to the RCRA closure plan activities will be deferred to the CERCLA RI/FS process. The RCRA closure of 303M has been deferred to the CERCLA process.

A significant unirradiated uranium inventory, present at the time that the $N$ Reactor standby was announced, is stored within the FSS complex. The majority of the material is in the form of extrusion billets. Part of the inventory is in the form of fuel elements, some of which were partially fabricated at the time operations ceased. A portion of the finished fuel had previously been loaded into the reactor, but never irradiated. This fuel was returned to 300 Area storage with low level fission and activation product surface contamination. In addition, 3.4 MT of unirradiated uranium dioxide powder, pellets, pins and assemblies, and 0.47 MT of thorium powder previously belonging to WHC Safeguards are stored in the south portion of the $303 \mathrm{~K}$ Building.

The uranium will be retained at the facility until an alternate storage facility or specific user has been found. The storage buildings will require continuing surveillance, maintenance, active fire systems, safeguards and security, and regulatory compliance until the uranium has been moved to an alternate facility or dispositioned. Relocation of remaining uranium inventory is currenlty planned in FY 1998. 
The RCRA closures involve the north half of the $303 \mathrm{~K}$ Building, as well as portions of several other buildings (303F, 313, 333, 334A Buildings, and 311 and 334 storage tank areas). Each of the closure plans describes the decontamination, sampling, characterization, and investigative studies to be performed for these facilities that will define their hazard potential and identify any remediation required. The plans are based on the expectation that little, if any, remediation work will be required, and that the facilities can be defined as clean closed. The plans are currently being reviewed or revised for some of these facilities.

The third major activity is to deactivate and clean up the remaining fuel supply facilities, or portions thereof, not associated with fuel storage or addressed in one of the RCRA closure plans. The result of this cleanup, as with the RCRA activities, will allow the buildings to be turned over to the ERC.

This deactivation, cleanup, and stabilization involves portions of all FSS buildings, as well as the process trench external to these facilities. Assets removed from these buildings are being disposed of in accordance with WHC and DOE regulations and procedures. Hazardous and radioactive material in these facilities will be cleaned up or stabilized in accordance with criteria specified for facility acceptance into the Hanford ERC program. Process and utility systems will be deactivated, or their operation limited to those required for safe, long-term custody while awaiting D\&D.

\subsection{STORAGE AND DISPOSITION OF SPECIAL NUCLEAR MATERIAL}

\subsubsection{A, 303B, 303E, 303G, 303K, 333, 3712, and 3716 Uranium Storage Buildings}

4.1.1.1 Building Descriptions. Special nuclear material is stored in seven buildings (303A, 303B, 303E, 303G, 333, 3712, and 3716) of the FSS complex. The total amount of SNM currently stored in these buildings is less than 1900 MT, consisting primarily of finished uranium fuel elements, partially finished fuel elements, and billets. This uranium material consists of $0.71 \%$ (natural), $0.95 \%$ and $1.25 \%{ }^{235} \mathrm{U}$ enrichments. Security, protection, and accountability will be required for this material until an alternate storage location or final disposition has been provided. A discussion of the options presented in the fuel relocation study (WHC 1994a) is contained in this plan. The options presented in the study will be reevaluated and appropriate planning documentation, environmental documentation, safety analysis, etc., will be prepared in FY 1997.

The current UK repackaging and shipment campaign will reduce inventory by $\sim 710$ MTU of billets. After completion of this campaign, the material at the 333 Building will be relocated, and the number of storage buildings will be reduced to five.

The 303A, B, E, and G Buildings, built in 1943, are single-story $8.2 \mathrm{~m}$ $\times 14.6 \mathrm{~m}$ ( $27 \mathrm{ft} \times 48 \mathrm{ft}$ ) munitions bunker-type buildings used as storage space for $N$ Reactor uranium billets and fuel elements. Each building contains three 
steel access doors, but has no windows. The buildings are constructed of concrete block with a concrete foundation and floor. The $46 \mathrm{~cm}$ (18 in) thick roof is a precast concrete slab with a tar and gravel surface. There is no heat or water in the buildings. The buildings are, however, equipped with an automatic fire suppression (dry) system with electrical heaters provided in the valve room. There are four $25 \mathrm{~cm}$ (10 in) diameter drain holes at floor level for water drainage in the event the sprinkler system is activated.

The 303A/B/E/G Buildings are used for storage of 705.95 MT of uranium billets and 174.23 MT of finished Zircaloy-2 clad $N$ Reactor fuel elements, all in wooden boxes. Uranium enrichments range from natural $(0.71 \%)$ to $1.25 \%$ ${ }^{235} \mathrm{U}$, with the majority being $0.95 \%$ The buildings are kept locked and sealed for SNM control.

The 3712 Building is a $27 \mathrm{~m} \times 33 \mathrm{~m}$ (90 ft $\times 108 \mathrm{ft}$ ) single story steel framed structure with metal panel siding and roof and a concrete foundation and floor. An automatic fire suppression (dry) system is provided. The building's steam heating and evaporative forced air cooling have been disconnected; however, electric heating is provided in the sprinkler system valve room. There is no water available, other than for fire suppression or floor drains in this building. Rollup door flaps are provided for drainage of any potential fire suppression system discharge. The building is used for storage of uranium billets and finished fuel in wooden boxes, uranium scrap and standards, and unfinished fuel pieces. Uranium enrichments range from $0.71 \%$ to $1.25 \%{ }^{235} \mathrm{U}$ with the majority being $0.95 \%$ The building is 1 ocked and sealed for SNM control. Storage capacity is 950 MT of uranium. The south side of this building has been modified to accommodate the repackaging of uranium billets for the UK campaign and to support the future packaging required for relocation of the remaining SNM inventory to an alternate location.

The $12.2 \mathrm{~m} \times 24.4 \mathrm{~m}(20 \mathrm{ft} \times 80 \mathrm{ft}) 3716$ Building is a one-story metal frame structure with insulated aluminum siding and roof. The structure is mounted four feet above grade on a concrete wall with concrete floor slab on grade. The building is equipped with an automatic fire alarm and sprinkler (dry) system. Floor drains provide a path for water drainage in the unlikely event of a sprinkler discharge. The steam heating system and evaporative cooler for the building have been secured. Electric heating is provided in the sprinkler system valve room. This building provides storage for $N$ Reactor nuclear fuels and for fuels manufacturing related supplies. Uranium enrichments range from natural $(0.71 \%)$ to $1.25 \%{ }^{235} \mathrm{U}$, with the majority being $0.95 \%$. The building is kept locked and sealed for SNM control. The capacity of the building for fuel storage is 250 MT of uranium.

The uranium pellets, powder, fuel pins and assemblies, and the thorium powder that are in the south portion of the $303 \mathrm{~K}$ Building will also require DOE disposition.

4.1.1.2 Scope. A fuel relocation study (WHC 1994a) was prepared to evaluate the available options for disposition of the 1900 tons of fuel material remaining within the FSS fuel storage buildings. Efforts are currently in progress to locate potential customers for purchase of the material. Based on evaluations and comparisons of the study, the recommended alternative is to 
transfer and consolidate the material at the $4732 \mathrm{C}$ warehouse in the 400 Area of the Hanford site, provided the building becomes available as currently envisioned, and the intent is to store the material until ultimate disposition of the remaining SNM.

The transfer of approximately $\sim 710$ MT of uranium billets stored in 303B and $303 \mathrm{G}$ to the UK is currently in progress. Completion of this agreement would remove the entire fuel inventory from the $303 \mathrm{~B}$ and $303 \mathrm{G}$ hutments.

Fue 7 consolidation at another onsite location, an option being considered to expedite withdrawal from the 300 Area, allows turnover of these buildings to the ERC. Because of the type of structures and current condition, there are no plans for major repairs or improvements (except possible roof repair). Completion of the storage mission for these facilities will require the following tasks to be performed for the $303 \mathrm{~A} / \mathrm{B} / \mathrm{E} / \mathrm{G}$ Buildings prior to turnover to ERC:

- Fire protection system layup

- All spare parts, tools and equipment removed

- Electrical services terminated

- All building penetrations closed off

- All doors secured.

The following tasks are required to complete the shutdown of the 3712 and 3716 Buildings prior to turnover to ERC:

- Fire protection layup

- All spare parts, tools, and supplies removed

- All attached hazardous materials identified and stabilized

- Temporary radiation zones in and out of buildings cleaned and released or stabilized

- All drains and effluent flow routes sealed, valved off or screened

- Electrical services terminated

- All building penetrations closed off

- All doors secured.

\subsection{RESOURCE CONSERVATION AND RECOVERY ACT CLOSURE PLANS}

Both the 304 concretion facility and the 300 Area solvent evaporator facility have been clean closed at FSS as of this date.

The remaining RCRA activities which involve the FSS buildings are described in the following RCRA closure plans:

- $\quad 303 \mathrm{~K}$ Radioactive Mixed-Waste Storage Facility Closure Plan (DOE-RL 1990b)

- 300 Area Waste Acid Treatment System Closure Plan (DOE-RL 1990C). 


\subsubsection{K Radioactive Mixed Waste Storage Building}

4.2.1.1 Building Description. The single story $8.2 \mathrm{~m} \times 14.6 \mathrm{~m}$ (27 ft $\mathrm{x}$ $48 \mathrm{ft}$ ) $303 \mathrm{~K}$ Radioactive Mixed-Waste Storage Facility has been used since 1943 to store various radioactive and dangerous materials and wastes generated by the fuel manufacturing processes in the 300 Area. The north room and outside fenced area is an approved treatment, storage, disposal (TSD) facility for greater than 90-day storage. This munitions bunker-type building contains no windows and is constructed of concrete block without interior insulation or wallboard. It has a concrete foundation and floor. The roof is a precast concrete slab with a tar and gravel surface. The building is currently in use as a waste storage facility; however, steam and water service have been secured, and all drains to the process sewer have been plugged. There is no fire alarm or sprinkler system provided for the building.

A cinder block wall constructed in 1953 divides the building into northern and southern halves. The dimensions of the north end of the building are approximately $7.5 \mathrm{~m} \times 7.6 \mathrm{~m}(24.5 \mathrm{ft} \times 25 \mathrm{ft})$. There is an exterior sliding door in the north wall and a personnel door in the west wall.

The mixed wastes were stored in the U.S. Department of Transportation (DOT) specification containers (DOT 1988). The north end of the building was used for the storage of containers of liquid waste, and the outside storage areas held solid waste containers. Revision 2A of the RCRA Closure Plan (DOE-RL 1990b) has been approved for public review by Ecology. The RCRA activities do not include the southern end of the building because only the north end of the building was in use as a TSD.

The outside storage areas consist of two concrete pads, two asphalt pads, and a gravel area. The outside storage area is approximately $426 \mathrm{~m}^{2}$ $\left(4,950 \mathrm{ft}^{2}\right)$. A fence constructed in 1978 around the perimeter of the facility limits access to the area. At the present time, solid wastes are stored on the outside storage areas in DOT-specified drums or low-level burial boxes.

4.2.1.2 Scope. The 303K facility will be closed in a manner consistent with Washington State guidelines and regulations. The 303K Storage Facility Plan (DOE-RL 1990b) has been reviewed by Ecology and accepted for public review as part of MOD B Site Part B permit review. The general closure approach to be implemented by the RCRA Closure Plan is as follows:

- Decontaminate for hazardous constituents the building components, walls, ceiling, the floor and the outside storage pads

- Collect samples from the building, floor, and outside storage pads

- Collect soil samples under the floor and pads in areas with potential pathways to the soil, if required

- Conduct analytical testing of samples and evaluate data results

- Compare data to action levels 
- Conduct additional decontamination for hazardous constituents of the building and outside storage pads, if required

- If decontamination procedures do not reduce contamination to acceptable levels, that portion of the building, floor, or pad will be removed. (if demolition is indicated, it is not included in this plan, and additional funding will be required). Those areas that cannot be clean closed will be stabilized and posted to prevent entry.

- It is the assumption of this plan that soil remediation, if required, will be accomplished under the CERCLA RI/FS process; however, written concurrence has not been received from Ecology.

A waste sampling and characterization plan has been developed for the 303K Building that will be implemented as part of the RCRA Closure Plan. The sampling plan includes the following activities to determine the dangerous waste constituents remaining following decontamination of the building and surrounding area:

- Determine whether the building surfaces, concrete floor, and outside storage areas contain dangerous waste constituents as defined by WAC 173-303 (Ecology 1991)

- Identify and quantify the specific dangerous waste constituents (if any) that are present using methods outlined in SW-846 (EPA 1986)

- Determine whether near-surface soils (no deeper than $3 \mathrm{ft}$ ) underlying the $303 \mathrm{~K}$ facility are contaminated above action levels as a result of operations at the facility

- Evaluate sample analyses data to determine initial actions and closure status.

Because of the type of structure, current condition, and potential for future utilization, there are no plans for major repairs, improvements, or upgrades for habitability, occupancy, or safety (with the possible exception of the roof). After the facility is RCRA closed, it may be used for storage of mixed or hazardous waste for less than 90 days until turned over to the ERC.

\subsubsection{Waste Acid Treatment System}

The WATS is a complex system of equipment, tanks, and piping located in portions of four buildings and two tank farms with in the FSS complex. The facilities include portions of the $303 \mathrm{~F}, 313,333$, and 334A Buildings and the 311 and 334 Tank Farms. Nonrecoverable uranium bearing waste acids treated in the 300 Area WATS were generated during fuel fabrication operations in the 333 Building. The acids were piped to the 334A Building holding tanks for temporary storage, then to the 313 Building. Neutralization of waste acid occurred in the south end of the 313 Building, which is called the uranium 
recovery area. Several types of acid were neutralized, including nitric acid, sulfuric acid, and hydrofluoric acid. Following neutralization and solids separation, wastes were pumped through the $303 \mathrm{~F}$ Building to Tanks 40 and 50 in the 311 Tank Farm Area.

Closure will include a portion of the facilities in the $303 \mathrm{~F}, 313,333$, and $334 \mathrm{~A}$ Buildings; as well as tanks in the 311 Area and one tank location (tank removed in 1988) in the 334 Area. In the 311 Tank Area, only tanks 40 and 50 are included in the 300 Area WATS Closure Plan. The other tanks were used to store pure nitric acid or sodium hydroxide. Tank 4 in the 334 Tank Area was disposed of previously, leaving only the tank pad to be closed. Tanks 7 and 11 in the 333 Building, used to reduce $\mathrm{Cr}^{+6}$ to $\mathrm{Cr}^{+3}$, are also a part of the system. The WATS in the 313 Building consists of several tanks, pumps, and associated filtering and centrifuge equipment at the extreme south end of the building.

A RCRA Closure Plan (DOE-RL-1990C) was prepared to decontaminate and sample the WATS to verify that constituents are not present in concentrations that represent a threat to human health or the environment. The 300 Area WATS will be clean closed in a manner consistent with Washington State guidelines and regulations. All of the applicable building surfaces, tanks, pads, and berms will be decontaminated. Pumps and interconnecting piping used to transfer the wastes will be cleaned or removed and disposed of according to regulatory requirements.

A revised WATS Closure Plan has been submitted to Ecology for review. Any notice of deficiencies that are recorded will be resolved and the plan updated. The WATS Closure Plan is scheduled for public review as part of NOD $C$ to the Site Part $B$ permit review. It is currently planned that RCRA closure field activities commence as follows:

$\begin{array}{lll}- & 313 \text { Building } & \text { FY } 1997 \\ - & 303 F \text { Building } & \text { FY } 1997 \\ \text { - } & 333 \text { Building } & \text { FY } 1997 \\ \text { - } & 334 A \text { Building } & \text { FY } 1997 \\ \text { - } & \text { 311 Tank Area } & \text { FY } 1998 \\ \text { - } & \text { 334 Tank Area } & \text { FY } 1998 \\ \text { Piping Trench } & \text { FY } 1998\end{array}$

Completion of all WATS Closure Plan activities is currently scheduled for 1999. If the closure plan is approved and TPA milestones are established that require completion before the above dates, this plan will be modified.

The WATS Closure Plan includes removal of all piping from the WATS piping trenches and backfilling and capping in FY 1998. Any further remediation of the pipe trenches that pass through and between FSS buildings will be evaluated under the CERCLA RI/FS process. Equipment used in performing closure activities at each facility will be decontaminated or disposed of at a RCRA-permitted facility. 


\subsubsection{303F Pumphouse}

4.2.2.1.1 Building Description. The $8.2 \mathrm{~m} \times 14.6 \mathrm{~m}(27 \mathrm{ft} \times 48 \mathrm{ft})$ $303 \mathrm{~F}$ Pump House is a concrete block structure with concrete foundation and floor. The building was used for storage and as a pumphouse for acid and caustics. The roof is a precast concrete slab with a tar and gravel surface. The steam to the building has been turned off, and there is no fire alarm sprinkler system. The building currently houses a caustic pump, caustic mix tank, a nitric acid pump, and two neutralized waste transfer pumps. All piping systems are in bermed areas.

Adjoining the $303 \mathrm{~F}$ Building is the 311 Tank Farm. It is located in a bermed area on the east side that can be manually drained to the process sewer. The tank farm contains two caustic tanks, a nitric acid tank, and two neutralized waste storage tanks. The caustic tanks contain a heel that must be removed, the nitric acid tank is empty, and the waste storage tanks are active.

A portion of WATS occupies a small area within the $303 \mathrm{~F}$ Pumphouse. Two WATS pumps, two in-line filters and associated piping located within a bermed area of the 303F Building are included in the WATS RCRA Closure Plan.

4.2.2.1.2 Scope. The approach to be implemented for the $303 \mathrm{~F}$ Building portion of the cleanup by the 300 Area WATS RCRA Closure Plan is as follows:

- Remove WATS pumps, filters, piping, and acid brick from bermed area

- Designate above equipment as to type of waste, appropriately packaged, and disposal

- Scabble concrete floor area within berm, if required, according to debris rule requirements.

Non-RCRA cleanup activities for the $303 \mathrm{~F}$ Building that require completion prior to turnover to the ERC are identified in Section 4.3 . It is the assumption of this plan that soil remediation, if required, will be accomplished under the CERCLA RI/FS process. However, written concurrence has not been received from Ecology.

Because of the type of structure, current condition, and potential for future utilization, there are no plans for major repairs, improvements, or upgrades for habitability, occupancy, or safety (with the possible exception of the roof). After completion of the WATS Closure Plan and cleanup of the remainder of the facility, it will be turned over to the ERC for demolition.

\subsubsection{313 Building}

4.2.2.2.1 Building Description. There are two types of construction associated with the $7,082 \mathrm{~m}^{2}\left(76,200 \mathrm{ft}^{2}\right) 313$ Building. A steel frame with exterior and interior walls of concrete block on grade provides the structure for the portion of the building south of the firewall. This area has a precast concrete slab roof with built-up tar and gravel surface. The north portion of the building has a steel frame with double metal insulated panel 
exterior walls with light-weight interior partitions. The floors are concrete or steel decking. The roof is insulated metal covered with a tar and gravel surface.

The building north of the firewall contains the $3,532 \mathrm{~m}^{2}\left(38,000 \mathrm{ft}^{2}\right)$ Hanford Metalworking Facility for extruding and finishing hollow or solid metallic shapes up to $17.7 \mathrm{~m}(58 \mathrm{ft})$ in length. The primary metal working equipment includes a 4000 ton extrusion press, a 125 ton draw bench, precision surface grinder and hone, autoclave, chemical cleaning bay, nondestructive examination instrumentation, and support equipment.

A two-story highbay $1118 \mathrm{~m}^{2}\left(12,033 \mathrm{ft}^{2}\right)$ just north of the firewall has a $230 \mathrm{~m}^{2}\left(2,476 \mathrm{ft}^{2}\right)$ mezzanine that contains the electrical switchgear and storage area.

The north portion of the building also contains ten offices, three conference rooms, and one change room.

Cooling for the process area of the building is provided by the roof-mounted air handlers. Steam to the heating coils and water to the evaporative coils have been turned off. Heating is provided by four wal1-mounted propane heaters.

Small air conditioners and heat pumps are used in the office area.

The north portion is equipped with an automatic wet pipe sprinkler system and a carbon dioxide system located in the exhaust duct of the 4000-ton press. Both systems are connected to the fire alarm panel, which is connected to the Hanford Fire Department.

South of the firewall, the building contains a $414 \mathrm{~m}^{2}$ (4453 $\mathrm{ft}^{2}$ ) Engineering Development Laboratory, the $85 \mathrm{~m}^{2}\left(916 \mathrm{ft}^{2}\right)$ Radiological Protection Laboratory, a $193 \mathrm{~m}^{2}$ (2081 $\mathrm{ft}^{2}$ ) copper preshape casting facility, which is in a standby condition, and a $159 \mathrm{~m}^{2}\left(1741 \mathrm{ft}^{2}\right)$ liquid waste treatment facility. The south area also has ten office areas (closed) and one change room (closed), as well as storage areas for miscellaneous supplies.

Ventilation for the south portion has been turned off. The wet pipe sprinkler system has been disconnected from the supply main and drained.

4.2.2.2.2 Scope. The following activities required by the WATS Closure Plan (DOE-RL 1990C) will be performed for the affected areas in the south portion of the 313 Building:

- Remove WATS tanks, centrifuge, filter press, pumps, and piping

- Designate above equipment as to type of waste, appropriately packaged, and disposal

- Debris rule requirements will be applied to the floor surface below the above equipment. This will involve the removal of acid brick and/or concrete floor scabbling. Acid brick and scabbling waste will be designated, appropriately packaged and disposal. 


\subsubsection{333 Building}

4.2.2.3.1 Building Description. The 333 Building is a two-story steel framed structure $91 \mathrm{~m} \times 42 \mathrm{~m}(300 \mathrm{ft} \times 140 \mathrm{ft})$ with insulated double metal panel walls. The foundation and ground floor are concrete, and the roof is insulated metal panels covered with felt, tar, and gravel. A mezzanine on the east side provides space for 21 (unoccupied) offices and electrical distribution equipment. A central mezzanine houses the ventilation equipment for the chemical bay, and a small mezzanine in the southwest corner accommodates a former lunchroom. A mezzanine on the north side provides space for six (unoccupied) offices. The mezzanine on the west side and the area below the mezzanine have been isolated. This area is heated and cooled by a heat pump system, is supplied with sanitary water, and is protected with a wet sprinkler system. The 12 offices are occupied by FSS staff. The remaining area is used as conference area, lunch area, and storage of supplies.

The building steam system has been disconnected. The water system has been disconnected except to above west mezzanine area.

The building houses the primary equipment previously used in the manufacturing of $\mathrm{N}$ Reactor fuel elements. This equipment is shut down.

4.2.2.3.2 Scope. The following activities required by the WATS Closure Plan will be performed for the affected areas of the 333 Building (tanks 7 and 11).

- Remove WATS tanks 7 and 11 and all piping from ten tanks that sent acid waste to WATS

- Designate above equipment as to type of waste, appropriately packaged, and disposal

- Debris rule requirements will be applied to the floor surface below the tank area; the concrete floor will be scabbled as required.

\subsubsection{334A Building}

4.2.2.4.1 Description. The 334A Building, built in 1974 , is a $6.1 \mathrm{~m} \mathrm{x}$ $12.2 \mathrm{~m}(20 \mathrm{ft} \times 40 \mathrm{ft})$ single story steel frame "Butler" type structure with insulated double metal panel walls. The foundation and floor are concrete, and the roof is insulated metal panel. The building superstructure was previously used elsewhere at Hanford before being moved to this location. The building houses three waste acid storage tanks and a transfer pump in a $3 \mathrm{~m}$ $(10 \mathrm{ft})$ deep concrete pit $31.8 \mathrm{~m}^{2}\left(342 \mathrm{ft}^{2}\right)$, which contains two $7,5701(2,000$ gal) plastic tanks and one 1,365 l (360 gal) stainless steel tank. There was also some minor storage of inactive process-related supplies. The building is inactive; however, electric space heaters, now deenergized, provided heat when active. The water has been shut off, and there is no automatic fire alarm system.

The 334A Building was used as an interim storage facility for waste acids with nonrecoverable uranium content from the 333 Building $N$ Reactor fuel element fabrication process. The waste acids gravity flowed into the tanks 
from the 333 Building in a 4 in. PVC drain line. A plastic pump in the pit transferred the waste acids through a 2 in. PVC pipe in a below-ground pipe trench to the 313 Building for neutralization.

The three storage tanks have been emptied and cleaned, the inlet and outlet piping removed, the plastic pump removed, the building drain from the pit is closed, and the water and electricity shut off. The three tanks cannot be removed without demolishing the west end of the building. The floor level is still used for miscellaneous storage.

4.2.2.4.2 Scope. The following activities required by the WATS Closure Plan will be performed for the affected areas of the $334 \mathrm{~A}$ Building:

- Remove all WATS piping

- Designate piping as to type of waste, appropriately packaged, and disposal

- Debris rule requirements will be applied to the floor surface and lower 0.9 meter $(3 \mathrm{ft})$ of wall surface; these surfaces will be scabbled as required

- The three tanks are to remain, and appropriate Debris rule cleaning of the tanks will be applied.

\subsubsection{311 Tank Farm}

4.2.2.5.1 Description. Recoverable and nonrecoverable uranium-bearing effluents from the 313 Building were combined in above ground tanks 40 and 50 in the 311 Tank Farm. The effluents were eventually transferred to tanker trucks for disposal in the 200 Area or were given to offsite TSD contractors for disposal if contents were below radioactive release limits.

Tank 40 was installed in 1953 and was used for storage of nitric acid until 1973. Since then, it was used to store neutralized waste prior to disposal. Tank 50, installed in 1985, was also used to store neutralized waste prior to disposal.

4.2.2.5.2 Scope. The following activities required by the WATS Closure Plan will be performed for the affected areas of the 311 Tank Farm:

- Remove all WATS pumps and piping

- Designate above equipment as to type of waste, appropriately packaged, and disposal

- Debris rule requirements will be applied to the floor surface and lower 30 centimeters (12 in.) of the Tank 40 catch basin wall surface; these surfaces will be scabbled as required

- The Tank 50 catch basin will be inspected for stains indicating hazardous constituent residue; if any is found, the catch basin and wall surface will be scabbled according to Debris rule requirements 
- The two tanks are to remain, and appropriate Debris rule cleaning of the tanks will be applied.

\subsubsection{334 Tank Farm.}

4.2.2.6.1 Description. Tank 4 in the 334 Tank Farm was used as an overflow for the tanks in the 334A Building. The tank was usually empty. However, during a period of usage, the tank developed a leak and was removed from service. The tank which previously comprised the 334 Tank Farm was removed in 1988, cleaned and buried. The WATS RCRA activity for this area will consist of closure of the concrete pad in the vicinity of the former tank.

4.2.2.6.2 Scope. The following activities required by the WATS Closure Plan will be performed for the affected area of the 334 Tank Farm:

- Tank 4 metal support structure and concrete pad beneath the tank will be inspected for stains indicating hazardous constituent residue; if any is found, these areas will be cleaned according to Debris rule requirements.

\subsubsection{Process Trench}

4.2.2.7.1 Description. The $434 \mathrm{~m}$ (1425 ft) Process Trenches served as an inter facility pipe chase between the 334 Tanks, 306W, 333, 334A, 303F, Caustic Unload Station, 311 Tanks and the 313 Building. The various sized concrete trenches are topped with removable reinforced concrete or steel panels. Only the WATS piping between the 313 Building and Tanks 40 and 50 remain in service. However, liquid spills within the 333 Building chemical bays and outside rain or snow run-off can enter the trench and empty into the 300 Area Process Sewer.

4.2.2.7.2 Scope. The trench within the FSS complex contains several contaminated piping systems and hazardous sediments. Environmental hazards are indicated, making it necessary to remove the piping and sediment and to clean up the trench before turnover. All piping will be removed from the trench. It is planned to further stabilize the trench and its residual inventory by installing fill material followed by a cap prior to turnover to the ERC (a total of 221 yards $^{3}$ of fill material required). The pipe trenches and process sewer that pass through and between FSS buildings will be evaluated under the CERCLA RI/FS process.

\subsubsection{Potential WATS Soil Contamination}

4.2.2.8.1 Description. The WATS Closure Plan proposes that soil sampling be performed if through-thickness cracks are found after concrete has been scabbled. If sampling is required, a sampling and analysis plan will be prepared for that activity. Discussions with Ecology indicate that Ecology may not approve clean closure of soil without sampling. This issue remains to be resolved. 
4.2.2.8.2 Scope. Any portion of WATS or affected area that cannot be clean closed will be stabilized, marked, and roped off to prevent access. Final closure of these areas will be completed by ERC. A post-closure inspection and monitoring plan will be prepared.

\subsection{BALANCE OF FACILITY CLEANUP}

This section discusses the cleanup criteria for the non-RCRA portions of those buildings that are included in a closure plan and for those FSS buildings that do not contain RCRA closure requirements.

The facilities that are completely free of RCRA requirements for closure include the 334 and $3707 \mathrm{G}$ Buildings and Trailer M0052. A portion of the 303F, 313,333 , and $334 \mathrm{~A}$ Buildings require RCRA closure as part of the WATS Closure Plan (DOE-RL 1990C). The 303M RCRA closure has been deferred to the CERCLA program. As discussed in this section, cleanup for the non-RCRA areas within these buildings is being accomplished separate from the RCRA procedures. Because environmental hazards are indicated, removal of all piping from the Process Trench and cleanup of the residual sediment will also be accomplished in conjunction with the WATS Closure Plan.

Any portion of FSS buildings that cannot be clean closed will be stabilized, marked, and roped off to prevent access. Final closure of these areas will be completed by the ERC. If, after decontamination, any equipment is found to be contaminated, it will be disposed of as mixed waste according to regulatory requirements.

\subsubsection{F Pumphouse/311 Tank Farm}

In addition to completion of the RCRA Closure Plan, the following task related to cleanup of the $303 \mathrm{~F}$ Building will require completion prior to turnover to the ERC:

- All unattached hazardous materials removed and dispositioned

- All attached hazardous materials identified and stabilized

- Caustic tanks and associated piping flushed and drained

- Electrical services terminated

- Water supply disconnected (safety shower and eye wash)

- All drains and effluent flow routes sealed, valved off or screened

- Al1 spare parts, tools, and equipment removed

- All building penetrations closed off

- All doors secured.

FY 1996.

The 311 Tank Farm caustic system work scope will be completed in 


\subsubsection{K Buitding}

In addition to completion of the RCRA Closure Plan, the following tasks related to cleanup of the $303 \mathrm{~K}$ Building require completion prior to turnover to the ERC:

- Remove all supplies from north and south rooms

- All attached hazardous materials identified and stabilized

- All spare parts, tools, and equipment removed

- Removal of all concreted containers of pyrophoric material (completed)

- Permanent radiation zones decontaminated or contained

- All building penetrations closed off

- Electrical services reduced

- All doors secured.

Following RCRA closure of the 303K facility, it may be used as a less-than 90-day storage facility for mixed and hazardous waste until the non-RCRA activities listed above are complete. Storage will also be provided for the 3.4 MT of the miscellaneous uranium powder, pellets, and pins and the thorium powder currently in the south portion of the building. Shipment of this material to an appropriate facility for storage or disposal is also planned for FY 1998 in conjunction with the 1200 MTU.

\subsubsection{Building}

Because of the type of structure, current condition, and the lack of potential for future utilization, there are no plans for major repairs, improvements, or upgrades for habitability, occupancy, or safety (with possible exception of the roof).

Cleanup in the 304 Building will be completed in FY 1996. The scope of the activity includes:

- Remove furniture and supplies

- All attached hazardous material identified and stabilized

- Water supply disconnected

- Permanent radiation zones decontaminated or stabilized

- Drains and effluent flow routes sealed, valved off, or screened

- Electrical services has been disconnected

- All building penetrations closed off

- Al1 doors secured

- Disconnect heat detectors.

\subsubsection{Building} company.

The north portion of the 313 Building is being leased by a private

With the exception of the 4000-ton Sutton Press in the north building, the majority of the fuel fabrication equipment has been removed from the building. 
The following non-RCRA-related 313 Building activities remain to be completed:

South portion of 313 Building

- Removal of combustibles from the building (completed)

- All attached hazardous materials identified and stabilized

- Remove fire alarm panel (will be relocated to a fuel storage hutment)

- Disconnect steam heating system (completed)

- Electrical service isolated to main breaker (future use required)

- Emergency lights removed and batteries dispositioned

- Stored radioactive waste removed

North portion of the 313 Building (after lease has expired)

- All janitorial supplies removed

- Removal office furniture and supplies

- Plug all drains

- Remove combustibles from north portion

- All attached hazardous materials identified and stabilized

- All hydraulic systems drained, analyzed, and disposal

- Electrical service isolated to main breaker (future use required)

- Water supply isolated for winter protection (future use required)

- Drain and isolate fire protection system piping

- Disconnect fire alarm master box

- Complete removal of the 4000-ton Sutton press and Hanford Metal Working Facility equipment.

Due to the deteriorating condition of the roof over the south portion of the 313 Building, a report was prepared (WHC 1994b) assessing the situation and providing a list of options for remediation. The most viable alternatives from a long-term perspective are demolition or isolation of the south portion of the building. The current approach is to isolate the 313 south portion of the building. The ERC contractor will initiate isolation in FY 1996, and this work scope will be completed in conjunction with the WHC RCRA and shutdown activities.

As part of the shutdown and isolation of the 313 Building, a new fire a] arm system master box will be installed in one of the fuel storage hutments to monitor the $303 \mathrm{~A} / \mathrm{B} / \mathrm{E} / \mathrm{G}$ fuel storage buildings. The current master box, servicing these buildings from the south portion of the 313 Building, will be removed as part of the shut down.

\subsubsection{Building}

The following non-RCRA related tasks are required to support the shutdown of the 333 Building:

- Fire protection layup

- Roof repair or replace

- Remove office furniture and supplies

- All spare parts, tools, and equipment removed 
- All janitorial supplies removed

- All unattached hazardous material removed

- All attached hazardous materials identified and stabilized

- All hydraulic systems drained or analyzed and disposed

- Electrical services reduced

- Water supply disconnected

- Stored radioactive and mixed waste removed

- Permanent radiation zones decontaminated or stabilized

- Plug all drains

- Emergency lights removed and batteries disconnected

- All building penetrations closed off

- All doors secured.

The following specific activities are required to complete removal of all unattached hazardous materials as required above:

- Clean out residues from uranium bearing acid storage, Tank 24

- Remove all chemical piping from chemical bays

- Inspect inside surfaces of chemical bay exhaust ducts and remove (or contain) any residual uranium bearing salts

- Inspect inside surfaces of beryllium exhaust ducts and remove any residual uranium and beryllium contaminated materials

- Remove HEPA filters from beryllium exhaust system.

\subsubsection{M Uranium Oxide Facility}

4.3.6.1 Building Description. The 303M Building is a precast concrete structure with concrete foundation and floor. The roof is a precast concrete slab with tar and gravel surface. All the water (including the fire system) has been turned off. Steam to the building has been isolated, and electricity and air have been turned off.

This inactive building contains calcinators used to burn Zircaloy-2 and uranium chips and fines. The facility consists of three rooms:

- An operations room with two calcinators, a chip chopper and material handling equipment (1085 $\left.\mathrm{ft}^{2}\right)$

- An equipment room with two HEPA filter banks and exhaust system $\left(700 \mathrm{ft}^{2}\right)$

- Change/monitor room (312 $\left.\mathrm{ft}^{2}\right)$.

4.3.6.2 Scope. A change control has recently been approved and signed by Ecology, EPA, and DOE. This officially deleted the 303M Building from the TPA milestone and added it to the 300-FF-2 (CERCLA) Operable Unit. A RCRA closure plan will, therefore, not be required. 
Clean up in the 303M Building will be completed in FY 1996. The scope of the activity includes:

- Fire protection layup

- Roof repair or replace (FY 1997-98 period)

- Remove office furniture and supplies

- All spare parts, tools and equipment removed

- All janitorial supplies removed

- All unattached hazardous materials removed

- All attached hazardous materials identified and stabilized

- All hydraulic systems drained, analyzed, and disposal

- All building penetrations closed off

- All doors secured

- Cleanup/removal of filters in the $303 \mathrm{M}$ process sewer filter house

- Removal and disposal of exhaust system HEPA filters

- Clean out of the dust collector bag house.

\subsubsection{Process Sewer Monitoring Building}

4.3.7.1 Building Description. The 334 Building, built in 1960 , is a $4.6 \mathrm{~m} x$ $6.1 \mathrm{~m}(15 \mathrm{ft} \times 20 \mathrm{ft})$ single story steel frame structure with double insulated metal panel walls. The foundation and floor are concrete. The shed roof is insulated metal panel covered with felt and roll tar paper topped with a gravel surface. The building has two metal doors and no windows. The building heat is provided by an electric heater. There is no automatic fire alarm system associated with this building. A floor trench on the south side discharges to the west into an outside pipe trench that drains into the 300 Area process sewer.

The process sewer monitoring system has been shut down. The building also contains the instrumentation for measuring the volume in the three out-of-service bulk acid storage tanks south of the 334 Building, which have been shut down.

4.3.7.2 Scope. Discharges to the 313 and 333 process sewers from FSS facilities are now limited to precipitation. No monitoring of $\mathrm{pH}$ is active.

Because of the location and small size of the building, there are no plans for major repairs, improvements, or reuse (with the possible exception of roof repairs).

The following tasks are required to be completed during the shutdown of the 334 Building:

- Roof repair or replace

- All spare parts, tools, and equipment removed

- All attached hazardous materials identified and stabilized

- All tanks and associated piping flushed and drained

- Electrical services reduced

- Water supply disconnected

- All drains and effluent flow routes sealed, valved off or screened.

- All doors secured. 


\subsubsection{A Building}

The following tasks are required to be completed during the shutdown of the 334A Building:

- Roof repair or replace

- Remove furniture and supplies

- All spare parts, tools, and supplies

- All unattached hazardous materials removed

- All attached hazardous materials identified and stabilized.

\subsubsection{G Change House}

4.3.9.1 Building Description. The $3707 \mathrm{G}$ Building is a single-story $3.7 \mathrm{~m} \mathrm{x}$ $4.9 \mathrm{~m}(12 \mathrm{ft} \times 16 \mathrm{ft})$ structure adjoining the west side of the 303K Building. The building has a concrete foundation and floor with metal panel siding and roof. Steam and water have been turned off. There is no fire alarm or sprinkler system.

4.3.9.2 Scope. The following tasks are required to complete the shutdown of the $3707 \mathrm{G}$ Building prior to turnover to the ERC:

- Remove furniture and supplies

- All attached hazardous materials identified and stabilized

- Electrical services reduced

- Temporary radiation zones in and out of building cleaned and released

- All drains and effluent flow routes sealed, valved off or screened

- All doors secured.

\subsubsection{M0052 Office Trailer}

The $8.5 \mathrm{~m} \times 20 \mathrm{~m}(27.8 \mathrm{ft} \times 66 \mathrm{ft})$ M0052 is an 11 office portable trailer with insulated metal panel walls and roof. The trailer frame is supported by metal stands on wooden plates. There is no fire alarm system for the building. Due to the condition of this facility, its use will be terminated in concurrent with the reduction in tenants in FSS facilities and identification of replacement facilities. The following tasks are required to be completed:

- Remove furniture and supplies

- Electrical services reduced

- All drains and effluent flow routes sealed, valved off or screened

- Disconnect water. 


\subsection{CLEANUP AND MATERIAL DISPOSITION}

\subsubsection{Equipment Disposition}

All movable equipment of value will be dispositioned as it becomes available. This is a continuous ongoing effort.

\subsubsection{Radioactive/Hazardous Material/Waste Disposition}

The principal facility liquid waste discharges to the 300 Area Process Sewer are HVAC and sump condensate, controlled and noncontrolled precipitation, and fire protection system releases. A description of Process Sewer discharges is contained in the Facility Effluent Monitoring Plan (WHC 1991b) as modified by the changes associated with discontinuing fuel fabrication activities. There are no anticipated radioactive liquid waste discharges. There are no planned releases or interconnections to the 340 Building radioactive liquid waste system.

Wastes generated from activities associated with the transition from standby to shutdown consist primarily of cleaning materials and those associated with operations in the surface contaminated areas.

Disposition of the 4,200 gallons of liquid stored in Tank 50 in the 311 Tank Farm has been completed.

\subsubsection{Cleanup/Decontamination}

Removal of bulk chemical inventories was completed in April 1991. cleanup of uranium residues from fabrication equipment has been completed to the extent known. The clean up has reduced radiological concerns and minimized the risk of spontaneous or accidental fires involving residual pyrophoric uranium chips and fines.

\subsubsection{Personnel Relocation}

Portions of the 333 Building and M0052 are used by FSS personnel. Personnel relocations from these buildings will be performed as required to accommodate the scheduled shutdown activities.

\subsection{DOCUMENTATION}

\subsection{Safety Analysis/Environmental Documentation}

An interim safety basis (ISB) has been approved to establish the safety basis for the FSS facilities in accordance with the Nonreactor Facility Safety Analysis Manual, WHC-CM-4-46 (WHC 1992b). The ISB, in conjunction with the interim operational safety requirements, will provide the required basis for 
interim operation and administrative controls for the facility during the transition to shutdown and until turnover to the ERC. The ISB also provides the authorization basis and safety envelope for consideration of unreviewed safety question issues as defined in DOE Order 5480.21 (DOE 1991) and WHC-CM-1-3, Management Requirements and Procedures, MRP 5.12 (WHC 1993a).

\subsubsection{Shutdown Documentation}

The engineering drawings, identified by the facility staff as necessary to directly support the safe shutdown of the FSS facilities, are identified as essential drawings. The list of essential drawings will be revised as necessary to reflect the transition to shutdown. Engineering change notices will be prepared as required to reflect changes to the essential drawings during the transitions to shutdown.

Upon completion of all physical work, documentation regarding this project will be finalized. Certified vendor information, procedures, records, drawings, etc., will be retained to the extent that they are availabie for turnover to the ERC. Documentation will also be available for verification of zero energy checks for all electrical circuits that were deenergized. The end state documentation will comply with the endpoint criteria (WHC 1996). 


\subsection{REFERENCES}

DOE 1991, Unreviewed Safety Questions, DOE Order 5480.21, U.S. Department of Energy, Washington, DC

DOE 1992a, Transition of Facilities to the Office of Environmental Restoration and Waste Management, Draft DOE Order 58XX.XX, U.S. Department of Energy, Washington, DC

DOE 1992b, Hazard Categorization and Accident Analys is Techniques for Comp 7 iance with DOE Order 5480.23, Nuclear Safety Analysis Reports, DOE Standard 1027-92, U.S. Department of Energy, Washington, DC

DOE-RL 1988, 300 Area Solvent Evaporator Closure Plan, DOE/RL-88-08, Rev 3B, U.S. Department of Energy, Richland, WA

DOE-RL 1990a, 304 Concretion Facility Closure Plan, DOE/RL-90-03, Rev 2A, U.S. Department of Energy, Richland, WA

DOE-RL 1990b, 303-K Radioactive Mixed-Waste Storage Facility Closure Plan, DOE/RL-90-04, Rev 2A, U.S. Department of Energy, Richland, WA

DOE-RL 1990c, 300 Area Waste Acid Treatment System Closure Plan, DOE/RL-90-11, Rev 1, U.S. Department of Energy, Richland, WA

DOE-RL 1993, Radioactive Waste Management, RLID 5820.2A, U.S. Department of Energy, Richland, WA

DOT 1988, Shipping Container Specifications, Title 49, Code of Federal Regulations, Part 178, U.S. Environmental Protection Agency, Washington, $D C$

Ecology et al. 1990, Hanford Federal Facility Agreement and Consent Order, Vols 1 and 2, Washington State Department of Ecology, U.S. Environmental Protection Agency, and U.S. Department of Energy, O1ympia, WA

Ecology 1991, Dangerous Waste Regulations, WAC 173-303, Washington State Department of Ecology, Olympia, WA

EPA 1986, Test Methods for Evaluating Solid Waste: Physical/Chemical Methods, SW-846, 3rd Edition, U.S. Environmental Protection Agency, Washington, $D C$

RCRA 1976, Resource Conservation and Recovery Act of 1976 as amended, Public Law 94-580, 90 Stat. 2795, 42 USC 6901, et seq.

WHC 1988a, 300 Area Fuel Fabrication Facility Transition to Standby P7an, Letter, Westinghouse Hanford Company to U.S. Department of Energy, Richland, WA, Correspondence Number 8853146

WHC 1988b, Operation Safety Requirements for Fuel Fabrication facilities in 300 Area, WHC-CM-5-31, Westinghouse Hanford Company, Richland, WA 
WHC 1991a, N Reactor Shutdown Program Plan, Rev 2, WHC-SP-0615, Westinghouse Hanford Company, Richland WA

WHC 1991b, Facility Effluent Monitoring Plan for the 300 Area Fuel Fabrication Facility, WHC-EP-0509, Rev 0, Westinghouse Hanford Company, Richland, WA

WHC 1992a, Solid Waste Management, WHC-CM-5-16, Westinghouse Hanford Company, Richl and, WA

WHC 1992b, Nonreactor Facility Safety Ana7ys is Manual, WHC-CM-4-46, Westinghouse Hanford Company, Richland, WA

WHC 1993a, Management Requirements and Procedures, WHC-CM-1-3, Identification and Resolution of Unreviewed Safety Questions, MRP 5.12, Westinghouse Hanford Company, Richland, WA

WHC 1993b, Implementation Plan for DOE Orders $5480.21, .22, .23$, Correspondence Number $9257875 \mathrm{Rl}$, Westinghouse Hanford Company, Richland, WA

WHC 1993c, Accident Safety Analysis for 300 Area N Reactor Fuel Fabrication and Storage Facility, WHC-SD-NR-RA-003, Westinghouse Hanford Company, Richland, WA

WHC 1994a, Options Analysis for Uranium Consolidation, WHC-SD-CP-ES-163, Westinghouse Hanford Company, Richland, WA

WHC 1994b, 313 Building Demolition, Letter J. A. Remaize, WHC, to J. E. Mecca, DOE, Correspondence Number 9451155

WHC 1994C, Hazard Categorization for 300 Area $N$ Reactor Fuel Fabrication and Storage Facility, WHC-SD-NR-HC-006, Westinghouse Hanford Company, Richland, WA

WHC 1994d, Fire Criticality Analys is for 300 Area N Reactor Fuel Fabrication and Storage Facility, WHC-SD-NR-TI-051, Westinghouse Hanford Company, Richland, WA

WHC 1996, End Point Criteria for Fuel Supply Shutdown Facilities, WHC-SD-NR-DB-004, Westinghouse Hanford Company, Richland, WA 


\subsection{ACRONYMS}

CERCLA Comprehensive Environmental Response, Compensation, and Liability Act

D\&D decontamination and decommissioning

DOE U.S. Department of Energy

DOT U.S. Department of Transportation

Ecology Washington State Department of Ecology

EM-60 Environmental Restoration and Waste Management

ERC

FSS

ISB

MT

MTU

MYPP

RCRA

RI/FS

SNM

TSD

TPA

UK Environmental Restoration Contractor

Fuel Supply Shutdown

interim safety basis

metric tons

metric tons of uranium

multi-year program plan

Resource Conservation and Recovery Act of 1976

remedial investigation/feasibility study

special nuclear material

treatment, storage, disposal

Tri-Party Agreement

United Kingdom

WATS

WHC

Waste Acid Treatment System

Westinghouse Hanford Company 


\section{Appendix A}

Fuel Supply Special Nuclear Material Inventory

METRIC TONS URANIUM MATERIAL

\begin{tabular}{ll}
648.6 & finished fuel \\
174.6 & finished fuel with surface contamination \\
234.5 & billets \\
139.8 & unfinished fuel and scrap \\
\hline
\end{tabular}

Total 1197.5

In addition, 3.4 MTU of unirradiated uranium dioxide powder, pellets, pins and assemblies and 0.47 MT of thorium powder belonging WHC

Safeguards are stored in the south portion of the 303K Building. 